\title{
Sustainable environmental geotechnics practices for a green economy
}

\section{António José Roque}

Senior Researcher, Geotechnics Department, Laboratório Nacional de Engenharia Civil, Lisboa, Portugal (Orcid:0000-0002-0971-6940)

(corresponding author: aroque@|nec.pt)

\section{Evan K. Paleologos}

Professor, Department of Civil Engineering, Abu Dhabi University, Abu Dhabi, UAE (Orcid:0000-0002-3582-2288)

\section{Brendan C. O'Kelly}

Associate Professor, Department of Civil, Structural and Environmental Engineering, Trinity College Dublin, Dublin, Ireland (Orcid:0000-0002-1343-4428)

Anh Minh Tang

Research Director, Ecole des Ponts ParisTech, Paris, France (Orcid:00000002-7149-8497)

\section{Krishna R. Reddy}

Professor, Department of Civil, Materials, and Environmental Engineering, University of Illinois at Chicago, Chicago, IL, USA (Orcid:0000-0002-6577-1151)

\section{Claudia Vitone}

Associate Professor, DICATECh Department, Politecnico di Bari, Bari, Italy (Orcid:0000-0001-6529-4167)

Abdel-Mohsen O. Mohamed

Professor, Uberbinder, Inc., Seattle, WA, USA; EX Scientific Consultants, Abu Dhabi, UAE (Orcid:0000-0002-0971-6940)

\section{Eugeniusz Koda}

Professor, Director of Institute of Civil Engineering, Warsaw University of Life Sciences - SGGW, Warsaw, Poland (Orcid:0000-0002-3895-960X)

Venkata Siva Naga Sai Goli

Research Scholar, Department of Civil Engineering, Indian Institute of Technology Bombay, Mumbai, India (Orcid:0000-0003-1916-725X)

\section{Castorina S. Vieira}

Assistant Professor, CONSTRUCT, Faculty of Engineering, University of Porto, Porto, Portugal (Orcid:0000-0001-6328-4504)

\section{Xunchang Fei}

Assistant Professor, School of Civil and Environmental Engineering, Nanyang Technological University, Singapore, Singapore (Orcid:0000-0002-7435-9011)

\section{Francesca Sollecito}

Post-doctoral, DICATECh Department, Politecnico di Bari, Bari, Italy (Orcid:0000-0002-4699-5248)

\section{Magdalena Daria Vaverková}

Associate Professor, Institute of Civil Engineering, Warsaw University of Life Sciences - SGGW, Warsaw, Poland; Faculty of AgriSciences, Mendel

University, Brno, Czech Republic (Orcid:0000-0002-2384-6207)

\section{Michael Plötze}

Senior Scientist, Institute for Geotechnical Engineering, ETH Zurich, Zurich, Switzerland (Orcid:0000-0001-9833-4196)

Rossella Petti

PhD student, DICATECh Department, Politecnico di Bari, Bari, Italy (Orcid:0000-0003-0111-3480)

\section{Anna Podlasek}

Assistant Professor, Institute of Civil Engineering, Warsaw University of Life Sciences - SGGW, Warsaw, Poland (Orcid:0000-0003-0326-5672)

Alexander M. Puzrin

Professor, Institute for Geotechnical Engineering, ETH Zurich, Switzerland (Orcid:0000-0002-9566-8841)

\section{Federica Cotecchia}

Full Professor, DICATECh Department, Politecnico di Bari, Bari, Italy (Orcid:0000-0001-9846-4193)

Piotr Osiński

Assistant, Institute of Civil Engineering, Warsaw University of Life Sciences - SGGW, Warsaw, Poland (Orcid:0000-0003-1503-7650)

\section{Arif Mohammad}

Post-Doctoral Research Fellow, Department of Civil Engineering, Indian Institute of Technology Bombay, Mumbai, India (Orcid:0000-0002-1815-5073)

Prithvendra Singh

Research Scholar, Department of Civil Engineering, Indian Institute of

Technology Bombay, Mumbai, India (Orcid:0000-0001-9979-7694)

Maisa El Gamal

Assistant Professor, College of Natural and Health Sciences, Zayed

University, Abu Dhabi, UAE (Orcid:0000-0001-5485-8510)

Sherine Farouk

Professor and Associate Dean, College of Business, Abu Dhabi University, Abu Dhabi, UAE (Orcid:0000-0001-5579-9727)

Moza T. Al Nahyan

Associate Professor, College of Business, Abu Dhabi University, Abu Dhabi, UAE (Orcid:0000-0002-5700-5043)

\section{Slobodan B. Mickovski}

Professor, School of Engineering and Built Environment, Glasgow

Caledonian University, Glasgow, Scotland (Orcid:0000-0002-1792-1258)

Devendra Narain Singh

D.L. Shah Chair Professor for Innovation, Department of Civil Engineering, Indian Institute of Technology Bombay, Mumbai, India (Orcid:0000-0003-3832-1507)

The revitalisation of the global economy after the Covid-19 era presents environmental geotechnics with the opportunity to reinforce the need for a change in paradigm towards a green, circular economy and to promote aggressively the use and development of sustainable technologies and management practices. This paper aims to assist in this effort by concentrating on several thematic areas where sustainability solutions and future improvements are sought. These include the re-entry of construction and demolition of wastes, excavated materials, industrial wastes and marine sediments into the production cycle and the reuse of existing foundations. Despite the recent trend in advanced countries towards recycling and waste-to-energy thermal treatment, landfills still constitute the most common municipal solid waste management practice, especially in low-and-middle-income countries, and technological solutions to improve their environmental footprint are hereby presented. At the same time, remediation solutions are required to address the multitude of contaminated sites worldwide. Advanced developments that incorporate environmental, economic and social dimensions are expounded by the authors, together with sustainable ground improvement solutions for infrastructure projects conducted in soft and weak soils. The topic of thermo-active geostructures concludes this paper, where, apart from their infrastructure utility, these structures have the potential to contribute to the renewable energy source.

Keywords: rehabilitation, reclamation \& renovation/renewable energy/waste management \& disposal 


\author{
Notation \\ K hydraulic conductivity \\ $w_{\mathrm{L}} \quad$ liquid limit \\ $w_{0} \quad$ water content
}

\section{Introduction}

Since the beginning of 2020, the Covid-19 health crisis has been added to existing global challenges that threaten the well-being of humankind. The pandemic has further exposed the relationship between the economic and social modes of operation and environmental problems. Thus, a reduction in atmospheric pollution over many cities has been observed during the lockdown; environmental noise has subsided and cleaner beaches and coastal waters have resulted from the much-reduced tourism. On the other hand, the pandemic has accentuated some environmental problems through the increase of waste production, significant reduction in waste recycling and entry of disinfectants into soils and waters (Paleologos et al., 2020; Tang et al., 2020; Vaverková et al., 2020).

The construction industry is a well-known source of negative environmental impacts due to the high consumption of natural resources and energy and the large production of waste (Farid, 2020). The environmental performance of the construction industry remains sub-standard, despite the fact that the principles of sustainability and circular economy can easily find application in this industry. This has become even more critical since the rate of extraction of natural resources has become 1.6 times higher than their capacity to regenerate.

Renovation, the replacement and retrofitting of aging building stock gives rise to the reuse of existing building materials and the development of new, more sustainable construction practices (European Commission, 2020b). This is assisted by the development of 'green' codes and regulations regarding the design, construction and operation of buildings (DMT, 2020; LEED, 2021). It becomes especially critical for the post Covid-19 recovery, which is seen by governments as an opportunity to 'transition to a greener and more sustainable economy', as exemplified by the joint declaration of the European Union (EU) and China on September 14, 2020 (European Commission, 2020a).

This paper aims to present an overview of and some recommendations regarding the reuse of several types of waste in geoenvironmental projects. Foundation reuse is a topic of interest, especially for older cities that are congested by a large number of infrastructure elements in their subsurface. The management of marine sediments has become important given the expansion of ports in many countries; and there's the need to retain the natural balance between waterways and sea to conserve coastal ecosystems, and to accommodate tourist, transportation and even desalination needs in an integrated manner. Waste and sediment management practices are being implemented in several countries with significant national action plans and regulations anticipated to accelerate these efforts.
Landfills remain the principal way to dispose solid waste across the world. The USA and especially the EU have moved to transition - away from landfilling to recycling and waste to energy, but for low and middle-income countries, the cost, lack of technological and organisational expertise and waste composition make landfilling a desirable option to the alternative use of open dumps. The challenges in the management of landfills are expounded in this paper and the use of sulfur concrete as a component of landfill barrier systems is presented, together with the emerging topic of mining landfills for the recovery of useful materials.

It has also become amply clear that improper disposal practices and accidental spills have resulted in the contamination of the geo-environment. Developers are generally hesitant to convert contaminated land into beneficial use, due to liability issues. Many initiatives have been undertaken, and environmental laws and regulations have been promulgated over the last 30 years to assist in the clean-up of brownfields, and to utilise such lands for housing and commercial needs as well as for natural reclamation (USEPA, 2020a). Thus, another theme of this paper is to discuss advanced developments in sustainable land remediation, and present sustainable ground improvement solutions in infrastructure projects conducted in soft, weak and unstable soils.

Geotechnical engineers are routinely involved in the design and construction of underground structures, such as tunnels, base slabs, piles and diaphragm walls. Apart from the role that these elements play as infrastructure, recent studies have shown that they may also be used for the production of shallow geothermal energy. The technological improvements in the design of thermoactive geostructures, together with the standardisation in their application, will assist market penetration and increase the interest in developing countries. Geo-structures may present an example of a situation where the synergy between a project's variable functions may be sought, and this constitutes the concluding theme of this paper.

\section{Sustainable waste management}

\section{Minimising and recycling of construction and demolition} waste (C\&DW)

Much of the focus in environmental geotechnics has been on recycling of non-hazardous industrial waste and the by-products of different origins and characteristics. The examples of the application of such materials in geotechnical works include: (i) C\&DW in road pavement layers, geosynthetic reinforced structures and drainage layers; (ii) steel slag in road pavement layers and drainage layers; (iii) waste tyres in embankments and drainage layers; (iv) quarry waste in road pavement layers and landfill liners or cover systems; and $(v)$ bottom ash from incineration of municipal waste in road pavement layers (Roque et al., 2020). Other non-hazardous industrial wastes and by-products studied for use in geotechnical works are coal fly ash, bottom ash and foundry sand. 
The prevention, reduction and reuse are top priorities in the waste management hierarchy and are critical especially for the construction industry, which utilises large amounts of new material and generates large volumes of waste. Two-fifths of the global raw stone, gravel and sand have been depleted as a result of the construction industry. In Europe, the construction industry was responsible for generating about $820 \mathrm{Mt}$ of C\&DW in 2012, about one-third of the total waste generated for the region that year (European Commission, 2019a), while consuming $12-18 \mathrm{Mt}$ of new construction material (Ecorys, 2014).

On the positive side, several indicators suggest that sustainability considerations are finding their way to the mainstream in construction projects, with numerous companies emphasising green design and construction practices. Credit-bearing 'green' systems that reward projects, which adapt sustainability methods in the design, construction and operation of buildings and neighbourhoods, include the US-developed LEED (Leadership in Energy and Environmental Design) (LEED, 2021). Projects certified by LEED have claimed impressive accomplishments, in terms of water and energy savings, recycling of materials, extensive green areas and so on. Some countries have made the use of sustainability codes mandatory for the construction industry, such as the United Arab Emirates, which requires all new projects constructed in Abu Dhabi after 2010 to attain a certain rating under the Estidama Pearl Rating System (DMT, 2020).

The important benefits from the reduction and reuse of C\&DW include the following: (i) cost savings from a decrease in mining activities, reduced material transport to and from construction sites, along with reductions in transportation and disposal of waste in landfills; (ii) lower carbon dioxide emissions from resource processing and transportation; (iii) increased competitive advantage through differentiation; and (iv) flexibility to adapt to more stringent policy requirements that are related to C\&DW generation and disposal (European Commission, 2019a, 2019b).

Geotechnical works can be responsible for the movement of large volumes of earth material with matching large energy consumption. Considerable quantities of excavation soil and rock are generated in transport infrastructures (e.g. roads, railways and subways), urban infrastructures (e.g. supply networks for electricity, gas, water, sewerage, telecommunications and drainage networks for flood prevention) and the multi-floor basements of large buildings. Despite the fact that an excavated material often presents characteristics that make it appropriate for reuse on-site or off-site, it is often disposed in landfills, or even dumped indiscriminately, along roads or streams. The benefits from reusing excavated soil and rock include savings of up to $14 \mathrm{~kg}$ of carbon dioxide per ton of soil, as well as material-handling cost savings of up to $85 \%$ (Magnusson et al., 2015).

To encourage the reuse of excavated material, be it clean or lightly contaminated, several countries have developed regulations (CL:AIRE, 2011; MTES, 2017) to support best management practices. These guidelines avoid the classification of excavated soil as waste, making commensurate savings owing to the avoidance of controlled disposal. Most regulations only allow the geotechnical improvement of excavated soil, but the French (MTES, 2017) and English-Welsh (CL:AIRE, 2011) guides also allow the chemical treatment of soil if it is contaminated.

Foundation reuse is another topic that has become progressively important in recent years because of an increased concern regarding ground congestion in urban areas and the need to maximise material reuse and minimise resource exploitation and waste production. In many older cities, especially in Europe, it is found that the urban reconstruction below ground level has become increasingly difficult and expensive, as this space is often crowded with existing infrastructure/services that include utilities, tunnels and shallow and/or deep foundations of buildings.

Aside from ground congestion, the drivers for foundation reuse are improvements in: (i) project delays; (ii) foundation costs; (iii) carbon dioxide emissions; (iv) waste production; and (v) archaeological preservation. Jones et al. (2017) presented a case where the reuse of the foundations of an old building, constructed in the mid-1970s, in a new nine-storey residential building yielded a cost savings of $\$ 178 \mathrm{k}$ and reduced the completion time of the project by 6 weeks. Tsubakihara and Yamashita (2005) calculated that the reduction in the volume of newly built piles and in carbon dioxide emissions was about 40 and $70 \%$, respectively, through the reuse of existing cast-in-place concrete piles. These authors claimed that the engineering advantages, with the reuse of old foundations, include the nondisturbance of the supporting ground and retention of the bearing capacity of adjacent piles and of the structural integrity of neighbouring buildings or underground structures.

The main problem with foundation-reuse design is often the lack of credible information about the original design and the as-built construction of existing foundations. Thus, despite the benefits of reusing old foundations, currently, such foundations tend only to be reused if the ground beneath a building is already occupied by them, or if at the site, there exist archaeological remains that must be preserved. Thus, in order to make foundations accessible to future interventions and reuse, a detailed information about their design and construction must be retained in current projects.

\section{Sustainable management of marine sediments}

Despite the fact that the total amount of sediments dredged from marine basins in Europe reaches 100-200 million $\mathrm{m}^{3} /$ year, current European directives do not report about the handling of dredged sediments in a comprehensive and uniform manner. In most cases, dredged sediments are still classified as 'waste' and the disposal in large fill-in basins is the most used practice with associated high environmental risks.

In this context, the stabilisation/solidification $(\mathrm{S} / \mathrm{S})$ treatment of sediments with binders and additives represents a promising option for managing marine sediments, which are dredged 
periodically in harbour areas, either for port effectiveness or for on-site remediation (SedNet, 2011). This solution is highly flexible since the most efficient mix of binders and additives can be designed, depending on both the chemo-mechanical features of the sediments at each site and the required performance of the selected recycling application. Treatments can be specifically customised, mainly to: (i) improve the hydro-mechanical properties of the sediments (Federico et al., 2016); (ii) prevent the release of toxic elements into the environment (Wang et al., 2018) and (iii) reduce the interference of contaminants with the binders' chemistry that may otherwise compromise the effectiveness of stabilisation. The treated sediments may be either recycled as aggregates for road construction, cemented mortars, fill material, and brick production or transformed into sustainable resources that are useful for port infrastructures (Wang et al., 2012, 2015).

Recent research aims to treat marine sediments by using effective and sustainable additives that comply with the lowering of carbon dioxide emissions through the minimisation of hydraulic binders (e.g. $900 \mathrm{~kg}$ of carbon dioxide per ton of clinker are required to produce the binders). This is the case, for example, of biochar (a by-product of thermochemical industry) as an eco-friendly adsorbent for the remediation of contaminated sediments or mussel shell flour (MSF) (Papadimitriou et al., 2017). The MSF is a by-product of the fish industry, the compound being made of calcium carbonates, which, after a specific treatment, form a flour that can be used in the partial substitution of cementitious binders for the chemical and hydromechanical stabilisation of sediments (Petti et al., 2022).

In this context, the Politecnico di Bari, Swiss Federal Institute of Technology Zurich and Italcementi - Heidelberg Cement Group perform experimental studies for the stabilisation of dredged sediments using sustainable binders of lower environmental impact, in which a part of the binder is replaced by MSF. Table 1 reports some geotechnical properties of the natural sediments from the Gulf of Taranto, in the south of Italy, both before and after treatment with either $8 \%$ Portland cement (Sed8PC) or 6\% Portland cement with $2 \%$ MSF (Sed6PC2MSF). All the values in Table 1 are corrected for the pore water salinity, as described in Sollecito et al. (2019).

Table 1 shows that the addition of $8 \%$ Portland cement (PC) to marine sediments (clay fraction $(\mathrm{CF}): 30.4 \%$ ) causes a significant increase in liquid limit $\left(w_{\mathrm{L}}\right)$, such as to classify the amended sediments (i.e. Sed8PC) as silts of high-plasticity, $\mathrm{MH}$, in

Table 1. Physical and state properties of natural and treated sediments with 8\% Portland cement (Sed8PC), or 6\% Portland cement with 2\% MSF (Sed6PC2MSF) (curing time: 28 days)

$\begin{array}{llllr}\text { Mix } & \boldsymbol{w}_{\mathbf{L}}: \% & \mathbf{P I}: \% & \boldsymbol{w}_{\mathbf{0}}: \% & \mathbf{C l}(-) \\ \text { Sed_UP } & 53.59 & 28.61 & 74.0 & -0.72 \\ \text { Sed8PC } & 86.50 & 32.20 & 66.95 & 0.61 \\ \text { Sed6PC2MF } & 85.17 & 29.83 & 66.47 & 0.63\end{array}$

$\mathrm{Cl}$, consistency index; PI, plasticity index, $w_{0}$, water content; $w_{\mathrm{L}}$, liquid limit
Casagrande's plasticity chart (ASTM, 2017a). It follows that the recorded increase in consistency index $(\mathrm{CI})$ is essentially due to the reduction in water content for the treated sediment. It is worth noting that the replacement of part of the PC with $2 \%$ MSF additive increases the $\mathrm{CI}$ of the produced material (i.e. Sed6PC2MF) with respect to that of the standard PC-mixture. Promising results have also been obtained from mechanical tests, both in compression and shear (Petti et al., 2022), comparing the mechanical response of the natural sediments with that of the same sediments treated with traditional cement and cement-MSF additives.

The study on the marine sediments from the Gulf of Taranto has also been emblematic in showing that the search for effective in situ and ex-situ treatments could become extremely challenging due to the recurrent heterogeneity and contamination that characterises natural environments that are close to industrial areas (Vitone et al., 2016, 2020). The preliminary results from these sediments confirm that multi-scale testing is necessary to explore the reactions occurring during the cementation process, noting also their effects on the treatment performance, especially when both additives and binders are used (Petti et al., 2022).

The framework defined for normally consolidated natural clays and the most used standards (ASTM, 2017a, 2017b) do not focus on soils containing sources of complexity such as those typical of marine sediments - that is, high content of organic matter, high carbonate content (e.g. fossils and shells), diatoms and pollutants. Indeed, organic matter may absorb water and promote the aggregation of clay-size particles to form a more open fabric and, as such, affect the soil consistency, activity and compressibility (Levesque et al., 2007). Moreover, microfossils and diatoms present in marine soils may be responsible for high plasticity, activity and compressibility even within samples of low CF, due to their capacity to trap water into the intraskeletal pore space. Lastly, salts and pollutants alter the thickness of the diffusive double layer of clay particles, thereby affecting the engineering properties of fine-grained soils, depending on their mineralogical composition. The presence of these contributions could have an impact firstly, on the geotechnical properties of marine sediments that makes them exhibit unexpected behavioural facets, and secondly, with engineering implications that have something to do with the effectiveness of remediation and recycling strategies.

The activity chart of these marine sediment samples show peculiar deviations from predicted soil facets (Figure 1(a)) (Vitone et al., 2020). The chaotic distribution in the chart is mainly due to some results from the most contaminated top layer $(0-1.50 \mathrm{~m}$ below sea floor), which do not show the expected increase in soil plasticity with $\mathrm{CF}$. Hence, some sediment samples exhibit high activity $(\mathrm{A}>1.25)$ because they can sustain high plasticity despite their low $\mathrm{CF}$. Conversely, others samples are in the low-activity region $(\mathrm{A}<0.75)$, due to their low plasticity and high $\mathrm{CF}$.

The standard testing procedures on sediments often fail in depicting their altered physico-chemical properties due to cross-contamination, salt diffusion, organic matter degradation and fossil abundance, that 


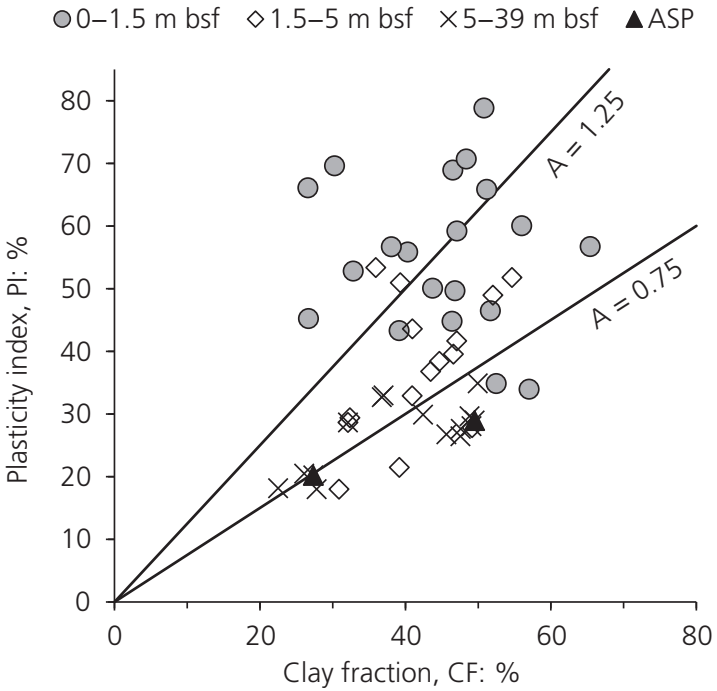

(a)

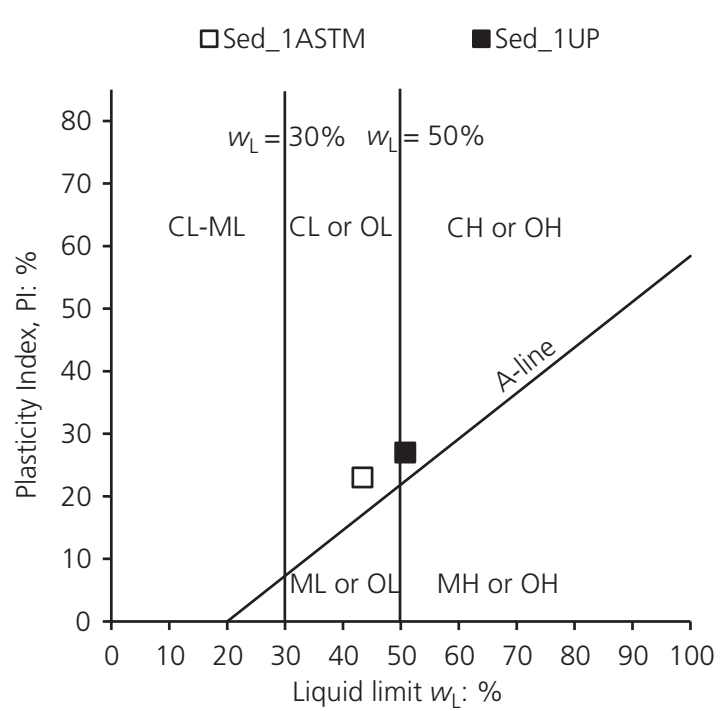

(b)

Figure 1. (a) Activity chart of the Gulf of Taranto marine sediments (Italy) collected down to $39 \mathrm{~m}$ depth (Vitone et al., 2020);

(b) Casagrande plasticity chart of a sediment sample from Gulf of Taranto. Sed_1ASTM, standard procedure; Sed_1UP, unconventional procedure (Petti et al., 2022); A, activity; ASP, sub-apennine clays, pleistocene; bsf, below sea floor; CL-ML, dual classification; CL, medium-to-low-plasticity clay; OL, low-plasticity organic soil; $\mathrm{CH}$, high-plasticity clay; $\mathrm{OH}$, high-plasticity organic soil

induce bias in measurements and classification (Sollecito et al., 2019; Vitone et al., 2020). As an example, the sieving procedure at No. 40 sieve (ASTM, 2017b), required by the standards for the Atterberg limit determination, removes the organic components and alters the sediment plasticity (Mitaritonna et al., 2013). As reported in Figure 1(b) for the marine sediments under study, the liquid limits and the plasticity index determined without sieving the sediments (Sed UP) are higher than those obtained according to the standard procedure (Sed_ASTM). It follows that the sediment can be classified as CL (medium-to-low-plasticity clay, (ASTM, 2017a) and CH (high-plasticity clay) if the Atterberg limits are determined with unconventional procedures based on of the whole material.

\section{Sustainable management of municipal solid waste}

(MSW)

\section{MSW generation, incineration and recycling}

The trend in MSW management in the USA and the EU is towards recycling, reduction of landfilling and increase of thermal treatment alongside with energy recovery. Thus, in the USA, recycling and composting increased from $10 \%$ in 1980 to $34.50 \%$ in 2012 , while waste-to-energy treatment accounted for $11.70 \%$ of the waste stream during the same year (Paleologos et al., 2016, 2018). For the 27 member states of the EU (EU-27), in 2018, recycling of the MSW had reached $47.40 \%$ (Eurostat, 2020b), whereas the 2016 data, which included the United Kingdom, showed an average of 20\% incineration across the 28 member states of the EU (Eurostat, 2020c). Per capita, the MSW generation in the EU has dropped slightly from an average of $1.41 \mathrm{~kg} /$ day (515 kg/annum) in 2015 to $1.35 \mathrm{~kg}$ /day (492 kg/annum) in 2018 (Eurostat, 2020c). The MSW generation in the USA is much higher and stood at $2.05 \mathrm{~kg} /$ day/capita in 2017 .
There has been a sharp increase in waste creation in the USA from the 1960 s to 1990 , and since then, per-capita production has stabilised between a minimum of $2.02 \mathrm{~kg} /$ capita/day, in 2010 , and a maximum of $2.15 \mathrm{~kg} / \mathrm{capita} / \mathrm{day}$, in 2000 (USEPA, 2020b).

The Organisation for Economic Co-operation and Development's data show a sharp increase in solid waste generation in the three largest economies over the last 27 years. Thus, the MSW generation, in kilotonnes (kt), was reported as: (OECD, 2020): in 1990, 227,417 in Europe, 188,939 in USA and 67,668 in China; in 2000, 277,344 in Europe, 220,854 in USA and 118,190 in China; in 2010, 279,011 in Europe, 227,749 in USA and 158,048 in China; and in 2017, 282,743 in Europe, 242,935 in USA and 215,209 in China (Figure 2).

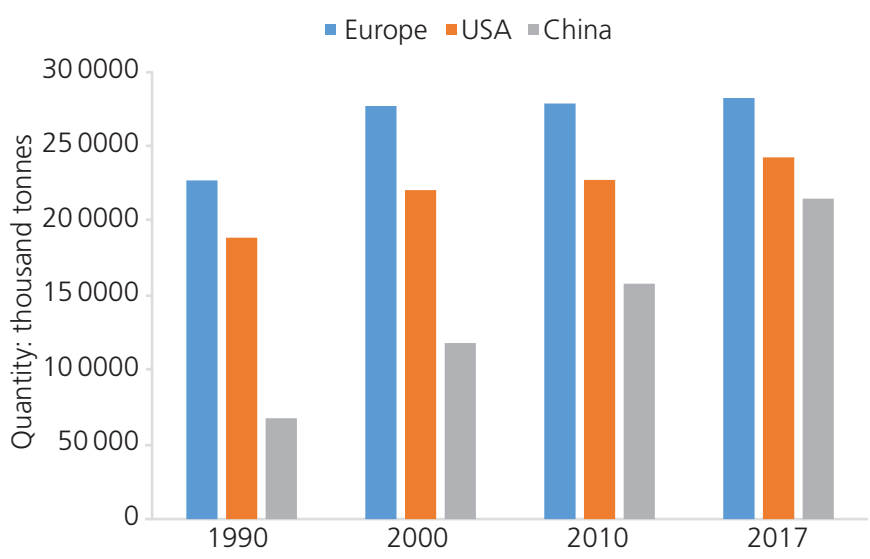

Figure 2. MSW generation (in kilotonnes) in the three largest economies (OECD, 2020) 
This means that from 1990 to 2017, each of the three largest economies increased their waste production, albeit at different rates, and from a combined 484,021 kt of waste in 1990 reached 740,887 kt of waste in 2017, which represents a cumulative $53 \%$ increase. It is clear that despite technological advancements, intensification of recycling efforts and public awareness campaigns, the continuous creation of new products and people's lifestyle and consumption patterns have created a problem that can be addressed only through a radical shift in both the economic and lifestyles paradigms.

Landfills have been an essential part in the waste management system, although the trend in most developed countries is away from landfilling and towards incineration tied with energy and heat recovery. The EU's Landfill Directives specifically state that according to the waste management hierarchy, landfilling is the least preferable option and should be limited to the necessary minimum' (European Commission, 2019b). The progressive move, away from landfilling and towards increased recycling and waste to energy in the EU is shown in Figure 3, where landfill use has steadily reduced during 2010-2016. In 2016, landfill constituted about... $23 \%$ of the total solid waste management options (Eurostat, 2020a). Some countries in Europe have done significantly better than this figure. For example, Belgium in 2016 sent only $3.80 \%$ of waste to landfills, $17.90 \%$ was incinerated and $78.20 \%$ of waste was recycled (Eurostat, 2020a). Denmark also sent about 4\% of its MSWs to landfills, incinerating about $54 \%$ of them, with the remaining being recycled (EEA, 2013). Slovenia is being quoted as a success story, in that prior to entering the EU, the country relied heavily on landfilling, but by 2018, it had almost reached the EU 2030 recycling target of $65 \%$ for MSW.

For developing nations, mainly Asian and African countries, landfilling is mostly adopted due to the difficulty of thermal treatment of MSW that exhibits high moisture content and low calorific value in these countries. In this context, bioreactor landfill, wherein the decomposition rate of the MSW is accelerated technologically by practising leachate recirculation, air purging or a combination of both and enhancing methane generation as an alternative energy source, can be used.

\section{Challenges and opportunities in landfill management}

The key issue in landfill management is to prevent and control harmful impacts to the environment over a period of many decades (Mohamed and Paleologos, 2018). During the Covid-19 pandemic, the waste management systems had to rapidly adjust to transport and dispose safely waste potentially contaminated by SARS-CoV-2 (Vaverková et al., 2020).

The survival of pathogens in clay barrier systems highly depends on soil hydraulic properties. Changing conditions in soil parameters, such as in hydraulic conductivity $(K)$, moisture content and ground temperature, determine the ability of the microorganisms to grow. When it comes to the unsaturated soil of the barrier system, where hydraulic properties are subject to significant changes (Tang et al., 2018), the development of microorganisms can become much more rapid than expected. Clay liners interact with viruses and bacteria depending on nutrient availability, soil $\mathrm{pH}$, medium temperature, moisture content and soil structure.

The complexity of virus interaction with host soils calls for new alternative barrier material to mitigate the transport of SARS-CoV-2 virus in clay liners. One example of such material may be elemental sulfur, which has found application in the construction and waste management industries (El Gamal et al., 2017; Mohamed and El Gamal, 2017). The use of sulfur concrete as a basic component of landfill barrier systems, to prevent migration of leachate to groundwater is shown in Figure 4. This barrier is a

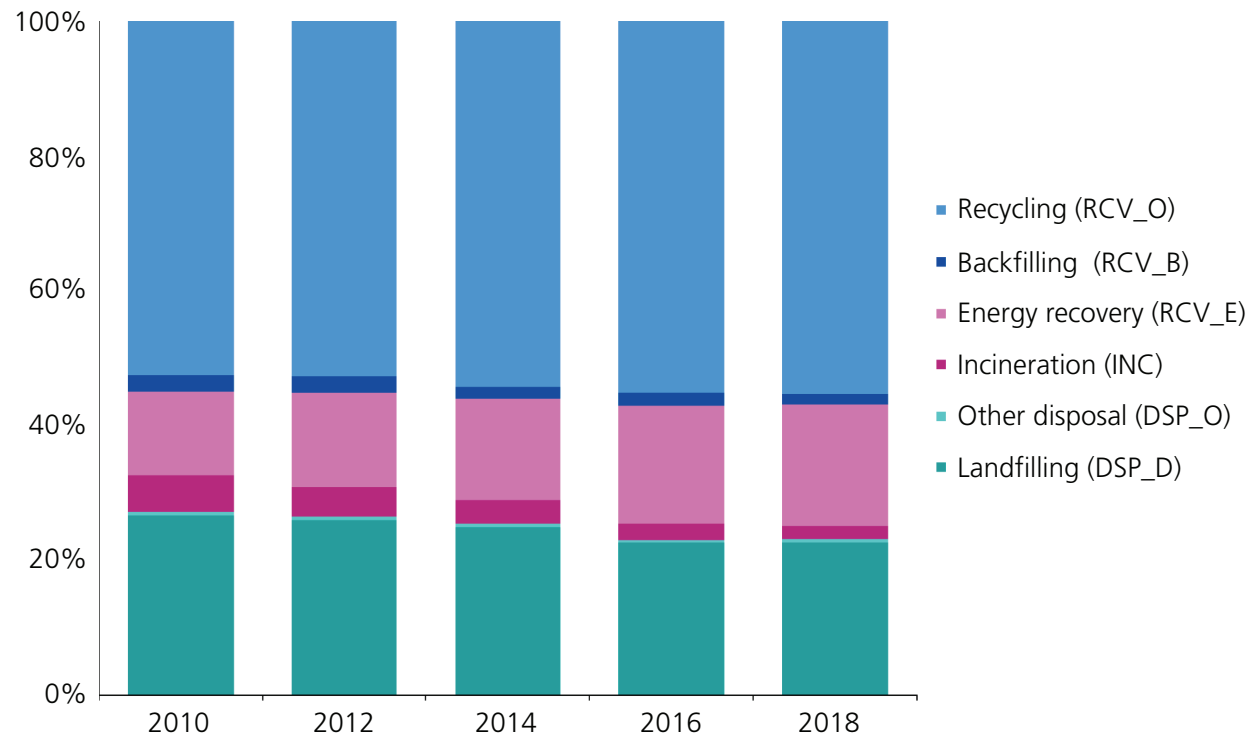

Figure 3. Treatment rates (\%) of waste by various routes in the EU for 2010-2018, excluding major mineral wastes (Eurostat, 2020a) 


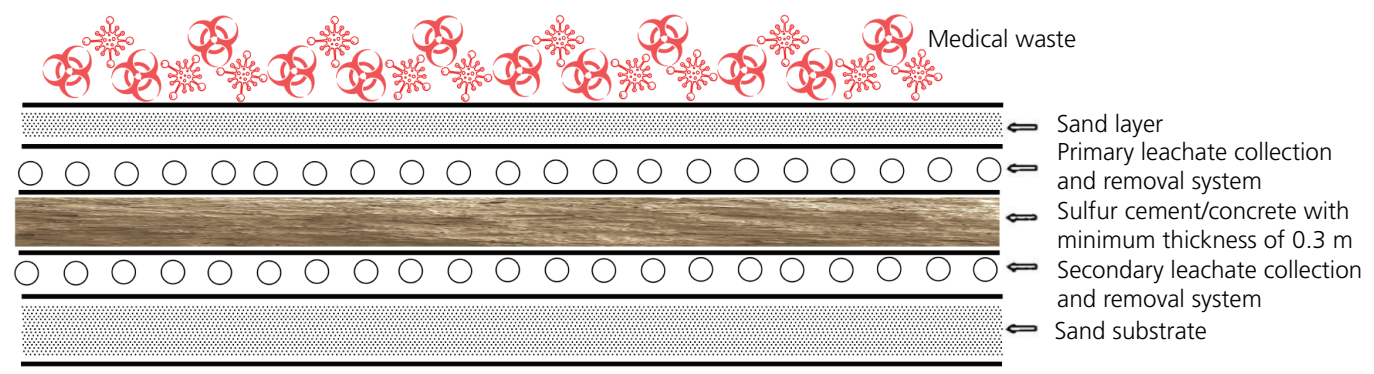

Figure 4. Design of MSC-containment construction barrier (modified after Mohamed and El Gamal, 2017)

multi-layered composite system, where an impermeable modified sulfur concrete (MSC) layer is placed in between the primary and secondary leachate collection and removal systems (LCRSs), surrounded by sand and sand-substrate layers (Mohamed and El Gamal, 2017). The liner consists of a layer of MSC with a minimum thickness of $0.30 \mathrm{~m}$. The MSC has a $K$ of the order of about $10^{-13} \mathrm{~m} / \mathrm{s}$, much lower than the value of $K=10^{-9} \mathrm{~m} / \mathrm{s}$ specified by the US Environmental Protection Agency (USEPA). The MSC has very low leaching rate in variable-pH environments, and has good resistance to chemical and physical degradation, so it retains its strength under different environmental conditions.

Since diffusion can be a significant contributor in the migration of contaminants carrying SARS-CoV-2, the porosity of constructed barriers is important. The very low $K$ of MSC is due to the significant low pore size distribution and the extremely low pore interconnectivity. Moreover, the use of microfillers in the production of MSC results in high bulk density barriers, which enhance isolation properties (Moosberg-Bustnes et al., 2004). Despite the small size of viruses and bacteria (typically of a diameter of around $60-140 \mathrm{~nm}$ in the case of the SARS-CoV-2 virus), the combination of the very low pore radius of the MSC (ranging from 38 to $110 \mathrm{~nm}$ ) and disconnected pores - in addition to the hydrophobic properties of sulfur - restrict the fluid flow paths through the concrete bulk, thereby preventing the leakage of toxic and medical hazardous components through the MSC barrier system.

Landfill mining has emerged, lately, as a way to recover metals, construction material, refuse-derived fuel and/or plastic from landfill sites (Canopoli et al., 2018). The interest in landfill mining arose from the fact that significant quantities of useful material have been buried, with US landfills alone holding over 589 million megatonnes (Mt) of metals (USEPA, 2014). As an example, the amount of copper deposited in landfills is estimated to be about 393 million tonnes $(\mathrm{t})$, comparable to the 330 million $\mathrm{t}$ of copper in use in the techno sphere (Krook et al., 2012).

In the EU, the total landfilled waste is estimated to be $30-50$ billion $\mathrm{m}^{3}$, which in the future may represent a valuable resource of metals and other materials. The recovery of plastic waste and landfill-mined, soil-like fractions have become the major driving forces for the economic viability of landfill mining due to the large fraction (20-70\%) of these in waste (Chandana et al., 2020).

\section{Geoenvironmental applications plastic and rubber reuse - zero waste discharge}

The extensive utilisation of plastic as an everyday commodity has led to its indiscriminate disposal in the geoenvironment. It has been estimated that around 4.9 billion $\mathrm{t}$ of plastic are discarded in landfills and the environment (Geyer et al., 2017). Discarded plastic degrades to micro- and nano-plastic, a critical situation because of the potential of plastic to have contaminants attached onto it, or to carry microbes, which, because of the size of the micro- or nano-particles, can move easily through different environmental media and pass to the food chain. Ngo et al. (2019) found micro-plastic in the influent, the sludge and the effluent that is released from wastewater treatment plants. Yonkos et al. (2014) detected micro-plastic in estuarine rivers, whereas O'Connor et al. (2019) and Panno et al. (2019) found it present in both the unsaturated and saturated zones. Recently, Ragusa et al. (2021) found that microplastics have entered the food chain, appearing even in human placenta. This necessitates the recycling of plastic waste into secondary products and their use in industrial, infrastructure and environmental applications. A summary of various products from plastic waste, the type of industry and method of application, together with the advantages and disadvantages of plastic waste utilisation, is presented in Table 2.

The increasing demand for rubber by various industries has led to the production of numerous rubber products that, at the end of life, create a substantial environmental burden due to their nonbiodegradability. The majority of rubber waste originates from discarded tyres, and it is estimated that by 2030, approximately 1,200 million tyres would be discarded annually (Thomas and Gupta, 2016). This constitutes a serious challenge, especially for developing countries that have insufficient landfills and a lack of technical and practical expertise in recycling and processing of rubber waste. The unsanitary disposal of rubber waste may create a breeding ground for mosquitos and other disease vectors; in general, to the contamination of the geoenvironment (Yung et al., 2013). 
Table 2. State of the art on plastic waste utilisation for geoenvironmental applications

\begin{tabular}{|c|c|c|c|c|c|}
\hline Industry & $\begin{array}{l}\text { Technique/method/field } \\
\text { of application }\end{array}$ & Products & Advantages & Disadvantages & References \\
\hline \multirow[t]{6}{*}{ Energy } & Incineration & Thermal energy & $\begin{array}{l}\text { Direct energy recovery and reduction } \\
\text { in the volume of waste }\end{array}$ & $\begin{array}{l}\text { Higher initial cost } \\
\text { Release of polychlorinated } \\
\text { dibenzodioxins/furans and } \\
\text { polycyclic aromatic hydrocarbons }\end{array}$ & Antelava et al. (2019) \\
\hline & Pyrolysis & $\begin{array}{l}\text { Bio-oil and } \\
\text { syngas }\end{array}$ & $\begin{array}{l}\text { Lower carbon footprint compared to } \\
\text { incineration }\end{array}$ & $\begin{array}{l}\text { Vulnerable to inconsistency in the } \\
\text { quality of the plastic waste }\end{array}$ & Qureshi et al. (2020) \\
\hline & & & $\begin{array}{l}\text { Production of a hydrocarbon-rich } \\
\text { gas/oil with a heating value of } \\
25-45 \mathrm{MJ} / \mathrm{kg} \\
\text { Flexibility to produce liquid/solid } \\
\text { products based on requirements }\end{array}$ & $\begin{array}{l}\text { Corrosion of reactors due to } \\
\text { release of polychlorinated } \\
\text { hydrocarbons and } \mathrm{HCl} \text { from PVC } \\
\text { degradation }\end{array}$ & \\
\hline & Gasification & Synthesis gas & $\begin{array}{l}\text { The synthesis gas is a desired } \\
\text { feedstock for production of fuels } \\
\text { such as dimethyl ether and methanol }\end{array}$ & $\begin{array}{l}\text { Inefficient fluidisation of the } \\
\text { feedstock due to agglomeration } \\
\text { of bed particles with plastic } \\
\text { waste }\end{array}$ & $\begin{array}{l}\text { Burra and Gupta (2018); } \\
\text { Lopez et al. (2018) }\end{array}$ \\
\hline & Hydrothermal carbonisation & Hydrochar & $\begin{array}{l}\text { Chemically activated porous hydrochar } \\
\text { can be used for energy storage } \\
\text { Co-hydrothermal carbonisation of } \\
\text { PVC and biomass helps in } \\
\text { dichlorination and removal of } \\
\text { inorganics from hydrochar } \\
\text { Organic chlorides can be converted } \\
\text { into water-soluble chlorides by } \\
\text { avoiding polychlorinated } \\
\text { dibenzodioxins/furans. }\end{array}$ & $\begin{array}{l}\text { Adulteration of alkalis required to } \\
\text { improve the dichlorination } \\
\text { efficiency }\end{array}$ & $\begin{array}{l}\text { Iniguez et al. (2019); Shen } \\
\text { (2020); Zhao et al. } \\
\text { (2020) }\end{array}$ \\
\hline & Chemical looping processes & $\begin{array}{l}\text { Thermal energy, } \\
\text { hydrogen or } \\
\text { methane } \\
\text { production }\end{array}$ & $\begin{array}{l}\text { Opportunity for } \mathrm{CO}_{2} \text { capture from } \\
\text { thermal treatment of plastic waste }\end{array}$ & $\begin{array}{l}\text { Sintering and agglomeration of the } \\
\text { oxygen carriers during the } \\
\text { process } \\
\text { Reduction in oxygen-carrying } \\
\text { capacity and combustion } \\
\text { efficiency }\end{array}$ & $\begin{array}{l}\text { Ma et al. (2019); Sai et al. } \\
\text { (2018) }\end{array}$ \\
\hline \multirow[t]{4}{*}{ Infrastructure } & Cement matrix composites & $\begin{array}{l}\text { Concrete, paver } \\
\text { blocks, tiles, } \\
\text { bricks }\end{array}$ & $\begin{array}{l}\text { Replacement of conventional coarse } \\
\text { and fine aggregates with plastic } \\
\text { waste } \\
\text { Production of lightweight construction } \\
\text { material }\end{array}$ & $\begin{array}{l}\text { Inferior mechanical properties due } \\
\text { to poor interaction between } \\
\text { cement and plastic aggregate }\end{array}$ & $\begin{array}{l}\text { Goli et al. (2020); Shah } \\
\text { et al. (2019) }\end{array}$ \\
\hline & Polymer matrix composites & $\begin{array}{l}\text { Wood-plastic } \\
\text { composites, } \\
\text { tiles and paver } \\
\text { blocks }\end{array}$ & $\begin{array}{l}\text { The replacement of cement-based } \\
\text { binders with plastic waste mitigate } \\
\text { the } \mathrm{CO}_{2} \text { emission from cement } \\
\text { production } \\
\text { Enhanced tensile strength and } \\
\text { durability due to less water } \\
\text { absorption }\end{array}$ & $\begin{array}{l}\text { Inferior mechanical properties due } \\
\text { to the immiscibility of the } \\
\text { heterogeneous polymers in } \\
\text { plastic waste } \\
\text { The lack of low-cost compatibilisers } \\
\text { hinders the upscaling process }\end{array}$ & $\begin{array}{l}\text { Goli and Singh (2021); } \\
\text { Basalp et al. (2020); Goli } \\
\text { et al. (2020); Dhawan } \\
\text { et al. (2019) }\end{array}$ \\
\hline & Soil reinforcement & - & $\begin{array}{l}\text { Useful for enhancing the strength and } \\
\text { stability of soils for embankments, } \\
\text { retaining structures and pavement } \\
\text { subgrades }\end{array}$ & $\begin{array}{l}\text { Leaching of toxic chemical } \\
\text { additives viz., polybrominated } \\
\text { diphenyl ether and heavy metals }\end{array}$ & $\begin{array}{l}\text { Salimi and Ghazavi (2019); } \\
\text { Chae and An (2018); } \\
\text { Peddaiah et al. (2018) }\end{array}$ \\
\hline & Pavement construction & $\begin{array}{l}\text { As a } \\
\text { replacement } \\
\text { to the asphalt } \\
\text { binder }\end{array}$ & $\begin{array}{l}\text { Enhances the durability, softening } \\
\text { point and fatigue life of the } \\
\text { pavement }\end{array}$ & $\begin{array}{l}\text { Lowering of cold cracking } \\
\text { resistance with increase in plastic } \\
\text { waste }\end{array}$ & $\begin{array}{l}\text { Vargas and Hanandeh } \\
\text { (2021); Appiah et al. } \\
\text { (2017) }\end{array}$ \\
\hline $\begin{array}{l}\text { Environmental } \\
\text { clean-up }\end{array}$ & Wastewater treatment & $\begin{array}{l}\text { As an adsorbent } \\
\text { for the } \\
\text { removal of } \\
\text { pollutants }\end{array}$ & $\begin{array}{l}\text { Biochars derived from plastic waste } \\
\text { adsorb dyes and heavy metals } \\
\text { present in wastewater } \\
\text { Higher volatile matter is helpful in } \\
\text { increasing the biochar porosity and } \\
\text { thus the specific surface area for } \\
\text { adsorption. }\end{array}$ & $\begin{array}{l}\text { The sorption capacity of the } \\
\text { biomass-derived biochars is more } \\
\text { as compared to plastic waste- } \\
\text { derived biochars }\end{array}$ & $\begin{array}{l}\text { Singh et al. }(2020,2021) \\
\text { Miandad et al. }(2018)\end{array}$ \\
\hline
\end{tabular}

$\mathrm{CO}_{2}$, carbon dioxide; $\mathrm{HCl}$, hydrochloric acid; PVC, polyvinyl chloride 
The current reuse of rubber waste includes tyre-derived fuel, moulded and extruded products, rubber-modified asphalt and sealants and ground-rubber applications in sport facilities' surfaces and walkways. Rubber waste utilisation in civil engineering applications include slope stabilisation, sound barrier, road construction, vibration dampener, and so on, while rubber-wastederived aggregates have been utilised as a lightweight fill material in embankments and retaining walls. For ameliorating the inferior geotechnical attributes of expansive clay, ground rubber, as an additive (Soltani et al., 2020), and synthetic polymer (polyacrylamide), as a binder (Soltani et al., 2019), have shown promise. The ground rubber additives also show promise for improvement in the liquefaction resistance of silty sand (Ghadr et al., 2021). Well-graded sand with nominally $10 \mathrm{wt} \%$ pulverised waste tyre material has shown promise to act as an adsorptive fill material for the removal of benzene, toluene, ethylbenzene and xylene components and heavy metals while providing adequate shear capacity for many load-bearing field applications (ShahrokhiShahraki et al., 2020). Rubber waste-derived aggregates can also be used in LCRSs due to their high $K$ values, which are much greater than the standard recommended value of $K=10^{-4} \mathrm{~m} / \mathrm{s}$ for the LCRS layers. Shredded rubber particles have found limited application in concrete casting as an aggregate replacement (Jalal et al., 2019), because they may reduce the concrete strength due to the hydrophobicity and low surface energy of rubber, which prevents good adhesion to the matrix (Nuzaimah et al., 2020). Finally, rubber waste applications are being explored for thermal and sound insulation (Thai et al., 2020) and as vibration dampeners to diminish/absorb the vibrational effects on structures.

More advanced reuse concepts, such as zero-waste discharge that includes zero-liquid-discharge (ZLD) and zero solid waste, have become mainstream practices. ZLD is a wastewater management approach that aims to recover and reuse the entirety of the industrial wastewater generated, resulting in zero discharge in the environment. ZLD was limited by the efficiency, energy requirements and cost of the thermal and membrane technologies on which it is based, but it is now driven by new regulations on effluent limitations in several countries (Yaqub and Lee, 2019). For example, in the USA, the first federal maximum pollutant concentrations, pre-treatment standards and best pollutant control technologies for effluent reduction from steam electric powergenerating plants were mandated (USEPA, 2015). China announced a new action plan in 2015, aiming to reduce water pollution substantially by 2030 . The measures in the Chinese action plan that favour ZLD are, among others, the control and reduction of pollutant discharge; financial incentives to promote the reuse of industrial, reclaimed and sea waters, as well as strengthening regulations, inspection and penalty structures; technological and management practices; and stakeholder participation. Finally, since 2015, the EU has launched a Circular Economy Action Plan (EU, 2015), which has motivated several major European industrial leaders to commit to ZLD and the principles of circular economy.

\section{Geoenvironmental applications for land improvement}

\section{Green developments in ground improvement and restoration}

Ground improvement works are challenging when problems of soft and weak estuarine clays, highly compressible peats, offshore marine muds and sensitive clays are encountered in infrastructure projects. Recent ground improvement solutions include the recycling of C\&DW instead of quarry-based raw materials; development of adsorptive load-bearing fill from recycled by-product materials, for the removal of organic/inorganic contaminants; and new, more efficient and environmentally friendly construction practices and technologies.

For instance, rather than importing engineering fill to a site, a marginal fill material already on-site, but with nominally too high moisture content, can be successfully incorporated in embankment construction operations, using geosynthetic inclusions that provide both reinforcement and drainage functions and/or amended with suitable industrial by-product materials. Limited life geosynthetics, fabricated from natural fibres, can replace conventional synthetic prefabricated vertical drains (PVDs) during the embankment foundation's consolidation stage. Lightweight fills, including recycled tyre bales and expanded clay aggregate, can be used in the embankment-core construction. Rather than employing surcharge preloading with PVDs to achieve acceptable residual settlements for embankments on soft compressible soil deposits, the vacuum preloading method can be used (Griffin and O'Kelly, 2014).

Major 'green' developments in the ground improvement sector include techniques and processes that are bioinspired. These include using naturally occurring/produced polymers (biopolymers) for soil mixing and grouting applications; bio-calcification of sandy soils using the microbial-induced carbonate precipitation (MICP) method (DeJong et al., 2013), which employs ureolytic bacteria, but more recently investigating indigenous to a given site bacteria, and the use of nanomaterials (e.g. nanosilica) for grouting treatments. Even the modest amounts of bonding between soil solids can produce sufficient real cohesion and significantly increase the near-surface strength for coarse-grained soil deposits. Together with the reduction of carbon footprint, many of the above, although presently at bench scale, have shown promise in replacing traditional cementitious and chemical additives. Biopolymers have also been tested in the manufacturing of earthen blocks for improved load bearing and durability performance.

Wind tunnel experiments have shown that the MICP technique of applying the spray treatment of the reagents (bacterial cell and urea-calcium chloride solutions) onto a loose sand surface layer has succeeded in stabilising this layer, with the potential to protect coastal sand dunes. The MICP technique using multiple staged injections of the reagents has also been shown to reduce internal 
erosion, one of the main causes of failure for hydraulic earthen structures (Amin et al., 2017)

Nano-silica (aqueous silica nanoparticles) has shown promise for grouting applications, producing a viscous gel property between soil particles to improve the liquefaction resistance, geotechnical load-bearing capacity and internal and surface layer erosion resistances of loose-to-medium sandy deposits (Gallagher and Mitchell, 2002).

Foundations and linear infrastructure bearing on expansive soil deposits can experience significant expansion/contraction during the absorption-desorption of a soil, leading to foundation distortion, wall cracking, undulation and cracking of road pavements and so on. Rather than using traditional cementitious/ calcium-based binders, the addition of sulfonated oil (a group of synthetic surfactants) has been shown to mitigate the swell-shrink volume change potential of expansive soil at a bench scale (Soltani et al., 2021).

Environmental geotechnics has been central to peatland management and restoration. These dynamic eco-hydrological wetland systems (and substantial carbon sinks) are increasingly under threat due to natural and anthropogenic pressures. One solution that has been proven effective in the field is the strategic construction of peat bunds (dams) at affected areas around the bog margins. These bunds can gradually re-establish the natural peatland hydrology and indigenous peat-forming vegetation through the collection, storage and controlled release of runoff from the high bog. Root reinforcement and slope bioengineering stabilisation have the ability to replace classically engineered interventions (e.g. piles, soil nails, ground anchors) with natural planting for the stabilisation or remediation of failures in natural and man-made slopes (Wood, 2013).

The use of geosynthetics in civil engineering often contributes to reductions in the cost of imported materials and the amounts of waste generated, compared with the use of soil, concrete or steel (Jones, 2015). Important cost savings related to materials' replacement associated to geosynthetics are found in landfills, where the volume of space saved by using thin geosynthetic materials instead of thicker mineral barriers is very significant. As reinforcement material, geosynthetics can be used to improve low-quality soils or alternative fill materials, such as C\&DW, dredged materials or other industrial non-hazardous wastes.

The use of recycled C\&DW as a fill material of geosyntheticreinforced structures (e.g. embankments, retaining walls) has shown very good overall performance. Geogrids and geocells have also been used to improve the performance of unpaved and paved roads made of recycled asphalt pavement (Gongora and Palmeira, 2012).

The use of dredged materials as backfill for geogrid-reinforced structures has been evaluated through pull-out tests (Kondo et al.,
2016). The coefficient of interaction between uniaxial geogrids and the dredged materials has been found to be slightly smaller than the value for clayey soils. Despite the lower performance of these to that of conventional materials, the environmental benefits can be important.

In mining applications, geosynthetic barriers can be used to reduce the environmental risks associated with contaminant migration and to improve the recovery of mine water (Bouazza, 2013). Geosynthetic materials, such as geopipes, geotextiles and geodrains, are also often incorporated into the drainage systems of tailing storage facilities or mining waste (waste rock) storage facilities.

The dewatering of slurry-like wastes, such as municipal waste, agriculture waste, food and food-processing waste, industrial and mining waste and contaminated sediments can also be performed through geotextile tubes, offering cost savings and environmental benefits.

The savings regarding the amount of materials and related costs vary with project conditions. A decrease of $30-40 \%$ in the aggregates, from the application of geosynthetics in road construction over soft soils (shear strength $<30 \mathrm{kPa}$ ) was reported by Christopher (2014). The International Geosynthetics Society Sustainability Committee has stated that geosynthetics can reduce the use of aggregate in infrastructure construction by over $50 \%$ and up to $90 \%$ in some cases (IGS, 2021). In drainage applications, the use of a geotextile filter wrapped around the open-graded aggregate allows a decrease in the dimensions of the drain trench typically on the order of $0.30 \mathrm{~m}$ in width, without a decrease in flow capacity (Christopher, 2014).

\section{Sustainable land remediation}

Land remediation involves site characterisation, risk assessment and remediation. Risk assessment can be complex due to incomplete knowledge of the hydrogeological conditions and of the physical, chemical and biological processes operating at a site, the contaminants' effects, uncertainties in the toxicity data and so on (Mohamed et al., 2020; Paleologos and Lerche, 1999).

Several innovative remediation technologies have been developed to reduce the risk by either removing the contaminants, or by transforming them into non-toxic forms or stabilising/ immobilising them in soil and groundwater. Such technologies for soil remediation include soil washing/flushing, soil vapour extraction, electrokinetic remediation, thermal treatment, phytoremediation and bioremediation, while for groundwater, the remediation applications include air sparging, permeable reactive barriers (PRBs), chemical oxidation/reduction and bioremediation (Shahrokhi-Shahraki et al., 2020). The use of a particular clean-up technology is mostly site-specific, and the cost and time needed for remediation can vary significantly, spanning hundreds of millions of dollars in clean-up costs and several decades of application (National Research Council, 1999). 
Some regulations have stipulated specific criteria for the selection of remediation technology; for example, a nine-point criteria scheme developed by USEPA (2008) for the clean-up of Superfund sites requires measures to: (i) protect human health and the environment; (ii) comply with applicable or relevant and appropriate requirements; and to provide: (iii) long-term effectiveness and permanence; (iv) reduction of waste toxicity, mobility and/or volume; (v) shortterm effectiveness; (vi) implementability; (vii) low cost; (viii) state acceptance; and (ix) community acceptance.

Conventional remediation approaches are not always sustainable, as they do not always account for broader environmental impacts, such as the extraction and use of natural resources, the wastes created and the energy used and related greenhouse gas (GHG) emissions for on- and off-site operations and transportation and the value lost from the residual degradation of a resource (Paleologos, 2008).

To address these deficiencies, some green and sustainable remediation (GSR) approaches have emerged (ITRC, 2011; SURF, 2009; USEPA, 2008). USEPA proposed the practice of considering all environmental effects of clean-up during each phase of the process and incorporating strategies to maximise the net environmental benefit of the clean-up as a green remediation concept (USEPA, 2008). The Sustainable Remediation Forum promoted a sustainable remediation concept that uses sustainable practices during the investigation, construction, remediation, redevelopment and monitoring of contaminated sites, with the objective of balancing economic viability, conserving natural resources and biodiversity and enhancing the quality of life in the surrounding communities (SURF, 2009). The Interstate Technology \& Regulatory Council (ITRC) introduced GSR, which is defined as the site-specific employment of products, processes, technologies and procedures that mitigate contaminant risk to receptors while making decisions that are cognizant of balancing community goals, economic impacts and environmental effects (ITRC, 2011).

The ITRC proposed a tiered sustainable remediation framework that represents the confluence of environmental, social and economic factors in decision making (ITRC, 2011). Specific quantitative assessment tools, such as SiteWise ${ }^{\mathrm{TM}}$ and Spreadsheets for Environmental Footprint Analysis, have been developed by federal agencies, such as the US Navy and USEPA, to quantify the metrics for environmental impacts. However, the tools to assess economic and social impacts are still being developed. The life cycle cost analysis and cost-benefit analysis methods are used for broader economic impact assessments. Monetised environmental costs (e.g. social cost of carbon) are also included as indirect sources of costs in such assessments (Reddy et al., 2019). The social aspects of sustainability include the consideration of the interests of all stakeholders, although social impacts are difficult to quantify (Reddy et al., 2014).

The resiliency of site remediation systems under changing climatic conditions and extreme weather events are of a growing concern to environmental remediation professionals. For example, the inundation of a contaminated site may adversely affect the bioremediation effectiveness in hydrocarbon-contaminated soils. Similarly, saltwater intrusion into coastal aquifers from a sea-level rise or any changes in groundwater elevations may have a negative impact on groundwater remediation by PRBs or chemical oxidation.

Finally, while the environmental dimension of sustainable remediation is well addressed, the economic and social dimensions are not yet fully developed and these require additional research. All stakeholders should be educated on the benefits of sustainable remediation. Incorporating resiliency into sustainable remediation is also emerging as an urgent need to the environmental remediation professionals.

\section{Clean energy production using thermo-active geostructures}

The use of engineering projects to accomplish supplementary goals to their original purpose has become more prevalent recently (Burra and Gupta, 2018). The final section of this article highlights a perhaps not-so-well-known area, where traditional ground structures (e.g. pile foundations, tunnel linings, diaphragm walls) can be used as heat exchangers, or as thermo-active geostructures for energy production (Laloui and Rotta Loria, 2019). The total number of such projects $(<200)$ still remains small compared to the total ground source heat pump installations worldwide.

The heat exchange in thermo-active geostructures is usually ensured by a heat pump system connected to heat exchanger pipes, embedded inside the geostructures during its construction, as a closed-loop geothermal system. A heat carrier fluid circulates inside the pipes to ensure the heat exchange between the geostructures and the heat pump. This system can be used for heating/cooling demands in residential buildings, for agricultural and industrial activities, to prevent the icing of pavements for transport infrastructures and so on. In addition to the advantages similar to the conventional shallow geothermal energy systems, energy geostructures use underground structures, which is already required for structural reasons.

Between various types of energy geostructures, piles are the most common. Piles have the potential to offer reduced capital cost compared to traditional vertical ground heat exchangers, such as boreholes. Moreover, as piles have a superficial resemblance to boreholes, there exist already available thermal design methods that can be adapted for use with piles. For instance, a thermal pile standard (GSHPA, 2018) has been developed from the vertical borehole standard, and various methods for the geotechnical design of piles subjected to thermal changes have been recently made available (Laloui and Rotta Loria, 2019). On the other hand, for other geostructures, some demonstration projects using slabs, walls and tunnels as ground heat exchangers exist, but there are no standard design or analytical approaches, and every new project must proceed on a case-by-case basis. 
Sani et al. (2019) presented an extensive review of research on energy piles and identified the effects of heating and cooling on building foundations to successfully design and install an energy pile system that will provide a highly-efficient, cost-effective and long-term solution for the heating and cooling demands of a building. Bourne-Webb and Bodas Freitas (2020) confirmed that thermal activation induces stress change and the deformation of the pile that depend on the boundary conditions (e.g. soil/pile/ superstructure interaction). The most recent studies related to energy piles focused on their long-term thermo-mechanical behaviour and group behaviour (Nguyen et al. 2020).

For other energy geostructures, the design methods are still under development. Numerical investigations (Barla and Di Donna, 2018) have proved the feasibility of energy tunnels; the exploitable heat of the tunnel lining was estimated at $10-20 \mathrm{~W} / \mathrm{m}^{2}$, when no groundwater flow is present, and up to $50-60 \mathrm{~W} / \mathrm{m}^{2}$, when there is significant groundwater flow. A comprehensive analysis of the energy performance and economic attractiveness of energy segmental linings for subway tunnels (Cousin et al., 2019) demonstrated that while the energy performance may be significantly enhanced, the most efficient design does not lead to the lowest LCOE (levelised cost of energy) and the earliest profitability. The observations on a real-scale experimental prototype of an energy tunnel (Barla et al., 2019) confirmed that this technology is mature for industrial application. A preliminary study on the geothermal potential assessment and thermal influences of a planned tunnel infrastructure at the city scale of Basel (Switzerland) illustrated the applicability of the developed methods to evaluate the general feasibility of the energetic use of tunnel structures (Epting et al., 2020).

For energy diaphragm walls, both energy and geotechnical aspects are still being investigated. Several numerical tools have been recently developed to maximise the energy performance of a diaphragm wall through the design of piping layout (Sterpi et al., 2020) or to evaluate the conductive and advective exchanged heat by the wall and the surrounding soil (Rammal et al., 2020). From the mechanical point of view, the thermal activation of a diaphragm wall would induce the additional bending moment and horizontal displacement of the wall. However, the computed stress variations are largely compatible with strength limits.

Although the scientific literature on the design and operation of shallow geothermal energy systems (including energy geostructures) has been increasing over the past years, this technology can be considered as a decentralised source of energy without being fully competitive yet (Tsagarakis, 2020). What hinders the wide penetration of these systems in most countries are issues related to high installation costs, administration, stakeholders' awareness and marketing. A recent review of the legal framework in shallow geothermal energy in several European countries (Tsagarakis et al., 2020) showed that a high diversity exists on legislation provisions, regulations, standards and institutional support. These authors suggested that this discrepancy acts as a barrier for the further development of the shallow geothermal energy market. They concluded that issuing appropriate technical rules and standardisation among EU countries would result in an increase of these energy systems' market. A common legislative EU framework will also benefit and affect other countries, especially developing countries, for which shallow geothermal energy applications are still in the early stages.

\section{Concluding remarks}

The overarching objective of the current paper is to put at the forefront some significant contributions in sustainable technologies and management practices across a broad range of environmental geotechnical projects, thus highlighting the important role of the discipline for the establishment of a green economy in the postCovid-19 era.

The authors have concentrated on three thematic areas, and the recent developments related to sustainability solutions in these areas, as well as in providing recommendations to overcome technological, regulatory and administrative obstacles. In view of the increased urbanisation in developing countries, the reuse of solid waste in the construction industry, given this industry's significant material and energy consumptions, as well as the quantity of waste generated, are of critical importance. Reusing C\&DW, excavated soil and rock and industrial waste, such as rubber and plastic, can find extensive application in road pavement layers, drainage projects, landfill cover and liners, embankments and other infrastructure projects, thereby resulting in significant savings in resource exploitation, transportation and waste disposal.

$\mathrm{S} / \mathrm{S}$ of marine sediments with binders and additives represents a promising alternative for managing marine sediments dredged periodically in harbour areas. Treated sediments may be used as aggregates for road construction, cemented mortars, fill material in brick production, or in port piers, shores and breakwaters. Treatment with additives, such as biochar or mussel shell flour, presents a more sustainable solution since it reduces the content of cement in the current cementitious binders and can achieve significant savings in carbon dioxide emissions during the clinker production of cementitious binders.

Despite the trend in advanced countries towards recycling and waste-to-energy initiatives, landfills constitute the most common MSW management practice. The complexity of virus interaction with host soils and the potential for transport of viruses through clay liners requires a rethinking of the material in landfill barriers. One example of such material may be elemental sulfur, through the use of modified sulfur concrete (MSC) as a component of landfill barrier systems, if only to prevent migration of leachate to groundwater. The MSC has a lower $K$ than that specified by USEPA for landfill barriers. Furthermore, it is an inert material, and has very low leaching rate in variable-pH environments, and good resistance to chemical and physical degradation. Its very low $K$ and extremely low pore interconnectivity may prove 
beneficial in hindering the migration of medical contaminants, such as those carrying SARS-CoV-2, through landfill liners.

Sustainable ground improvement solutions include recycling of C\&DW instead of using quarry-based raw materials; development of adsorptive load-bearing fill from recycled by-product materials, for the removal of organic/inorganic contaminants; novel foundation systems instead of conventional concrete foundations; and the embedment of new, more efficient and environmentally friendly construction practices and technologies. Instead of using traditional cementitious/calcium-based binders, foundations and linear infrastructure constructed on expansive soil deposits may use sulfonated oil or ground rubber, recycled from scrap tyres, and synthetic polymer, as a binder, to mitigate the swell-shrink volume change potential.

Geosynthetics play a major role in the drainage, barrier and final cover systems of landfills, and in mining applications, and their use contributes to significant reductions in the cost of imported materials, and the quantity of waste generated, thus providing a more efficient use of natural resources compared to traditional approaches that use soil, concrete or steel.

At the same time, remediation solutions are required to address the multitude of contaminated sites worldwide. Advanced developments that incorporate environmental, economic and social dimensions are presented herein.

Finally, the topic of thermo-active geostructures concludes this paper, where, apart from their infrastructure utility, these structures have the potential to contribute to the energy mix as a renewable energy source.

Thus, the benefits of adapting the above technologies and practices include, among others, waste minimisation and promotion of reuse and recycling; preservation of natural resources; improvement of waste management systems; reduction of the threats to soil and groundwater contamination; and reduction of the carbon footprint and greenhouse gas emissions. Altogether, the presented topics may provide a blueprint for a path forward to environmental geotechnics in achieving more sustainable and cost-effective solutions and the development of more resilient infrastructures and greener societies.

\section{Acknowledgements}

The second author would like to acknowledge the support of the Office of the Associate Provost for Research and Academic Development at Abu Dhabi University, UAE through grant 19300540.

\section{REFERENCES}

Amin M, Zomorodian SMA and O'Kelly BC (2017) Reducing the hydraulic erosion of sand using microbial-induced carbonate precipitation. Proceedings of the Institution of Civil Engineers - Ground Improvement 170(2): 112-122, http://doi.org/10.1680/jgrim.16.00028.
Antelava A, Damilos S, Hafeez S et al. (2019) Plastic Solid Waste (PSW) in the context of Life Cycle Assessment (LCA) and sustainable management. Environmental Management 64: 230-244, https://doi. org/10.1007/s00267-019-01178-3.

Appiah JK, Berko-Boateng VN and Tagbor TA (2017) Use of waste plastic materials for road construction in Ghana. Case Studies in Construction Materials 6: 1-7, https://doi.org/10.1016/j.cscm.2016.11. 001.

ASTM (2017a) D2487-17e1: Practice for classification of soils for engineering purposes (unified soil classification system). ASTM International, West Conshohocken, PA, USA.

ASTM (2017b) D4318-17e1: Test methods for liquid limit, plastic limit, and plasticity index of soils. ASTM International, West Conshohocken, PA, USA.

Barla M and Di Donna A (2018) Energy tunnels: concept and design aspects. Underground Space 3(4): 268-276, https://doi.org/10.1016/j. undsp.2018.03.003.

Barla M, Di Donna A and Insana A (2019) A novel real-scale experimental prototype of energy tunnel. Tunnelling and Underground Space Technology 87: 1-14, https://doi.org/10.1016/j.tust.2019.01.024.

Basalph D, Tihminlioglu F, Sofouglo SC, Inal F and Sofouglo A (2017) Utilization of municipal plastic and wood waste in industrial manufacturing of wood plastic composites. Waste and Biomass Valorization 11: 5419-5430, https://doi.org/10.1007/s12649-02000986-7.

Bouazza A (2013) Geosynthetics in mining applications. In Proceedings Geoafrica 2013, 2nd African Conference on Geosynthetics. Geosynthetica, Austin. TX, USA, p. 4.

Bourne-Webb PJ and Bodas Freitas TM (2020) Thermally-activated piles and pile groups under monotonic and cyclic thermal loading - a review. Renewable Energy 147(2): 2572-2581, https://doi.org/10. 1016/j.renene.2018.11.025.

Burra KG and Gupta AK (2018) Synergetic effects in steam gasification of combined biomass and plastic waste mixtures. Applied Energy 211: 230-236, https://doi.org/10.1016/j.apenergy.2017.10.130.

Canopoli L, Fidalgo B, Coulon F and Waglang ST (2018) Physico-chemical properties of excavated plastic from landfill mining and current recycling routes. Waste Management 76: 55-67, https://doi.org/10. 1016/j.wasman.2018.03.043.

Chae Y and An Y-J (2018) Current research trends on plastic pollution and ecological impacts on the soil ecosystem: a review. Environmental Pollution 240: 387-395, https://doi.org/10.1016/j.envpol.2018.05.008.

Chandana N, Goli VSNS, Mohammad A and Singh DN (2020) Characterization and utilization of landfill-mined-soil-like-fractions (LFMSF) for sustainable development: a critical appraisal. Waste and Biomass Valorization 12: 641-662, https://doi.org/10.1007/s12649020-01052-y.

Christopher BR (2014) Cost savings by using geosynthetics in the construction of civil works projects. Proceedings of the 10th International Conference on Geosynthetics (Ziegler M, Braü G, Heerten G and Laackmann K (eds)). German Geotechnical Society, Essen, Germany, p. 19.

CL:AIRE (2011) The Definition of Waste: Development Industry Code of Practice. Version 2. Contaminated Land: Applications in Real Environments (CL:AIRE), London, England.

Cousin B, Rotta Loria AF, Bourget A, Rognon F and Laloui L (2019) Energy performance and economic feasibility of energy segmental linings for subway tunnels. Tunnelling and Underground Space Technology 91, https://doi.org/10.1016/j.tust.2019.102997.

DeJong JT, Soga K, Kavazanjian E, Burns S and Van LA (2013) Biogeochemical processes and geotechnical applications: progress, opportunities and challenges. Géotechnique 63(4): 287-301, https:// doi.org/10.1680/geot.SIP13.P.017.

DMT (Department of Municipalities and Transport) (2020). Pearl Building Rating System. Abu Dhabi Urban Planning Council, Abu 
Dhabi, UAE. See https:/www.dmt.gov.ae/en/Urban-Planning/PearlBuilding-Rating-System (accessed 06/10/2020).

Ecorys (2014) Resource Efficiency in the Building Sector. Ecorys, Rotterdam, the Netherlands. See https://ec.europa.eu/environment/ eussd/pdf/Resource $\% 20$ efficiency $\% 20$ in $\% 20$ the $\%$ 20building $\%$ 20sector.pdf (accessed 07/06/2020).

EEA (European Environment Agency) (2013) Municipal Waste Management in Denmark. EEA Report, Copenhagen, Denmark, p. 16. See file://C:/Users/Evangelos/Downloads/Denmark MSW.pdf (accessed 09/10/2020).

El Gamal MM, El-Dieb AS, Mohamed AMO and El Sawy KM (2017) Performance of modified sulfur concrete exposed to actual sewerage environment with variable temperature, humidity and gases. Journal of Building Engineering 11: 1-8, https://doi.org/10.1016/j.jobe.2017.03. 009.

Epting J, Baralis M, Künze R et al. (2020) Geothermal potential of tunnel infrastructures - development of tools at the city-scale of Basel, Switzerland. Geothermics 83, https://doi.org/10.1016/j.geothermics. 2019.101734.

EU (European Union) (2015) EU Circular Economy Action Plan, European Commission, Brussels, Belgium. See https:/ec.europa.eu/ environment/circular-economy/ (accessed 12/07/2020).

European Commission (2019a) Construction and Demolition Waste. European Commission, Brussels, Belgium. See http://ec.europa.eu/ environment/waste/construction_demolition.htm (accessed 02/01/2019).

European Commission (2019b) Environment: Waste. European Commission, Brussels, Belgium. See https://ec.europa.eu/environment/ waste/landfill index.htm (accessed 10/102020).

European Commission (2020a) EU-China Leaders' Meeting: Upholding EU Values and Interests at the Highest Level. European Commission, Brussels, Belgium. See https://ec.europa.eu/commission/presscorner/ detail/en/ip 201648 (accessed 03/10/2020).

European Commission (2020b) Energy Performance of Buildings Directive. European Commission, Brussels, Belgium. See https://ec. europa.eu/energy/topics/energy-efficiency/energy-efficient-buildings/ energy-performance-buildings-directive_en (accessed 03/10/2020).

Eurostat (2020a) Waste Management Indicators: Statistics Explained. Publications Office of the European Union. Luxembourg, Luxembourg. See https://ec.europa.eu/eurostat/statistics-explained/ index.php?title=File:Treatment_rates_for_domestically generated waste excl major mineral wastes in the EU, 2010_to_2018_(\%25)_png\#file (accessed 19/10/2021).

Eurostat (2020b) Recycling Rate of Municipal Waste. Publications Office of the European Union. Luxembourg, Luxembourg. See https://ec. europa.eu/eurostat/databrowser/view/sdg 11 60/default/table?lang=en (accessed 18/07/2020).

Eurostat (2020c) Waste Management Indicators. Publications Office of the European Union. Luxembourg, Luxembourg. See https://ec.europa. $\mathrm{eu} /$ eurostat/statistics-explained/index.php?title=Waste management indicators\&oldid=308871\#Incineration_including_energy_recovery (accessed 18/07/2020).

Farid A (2020) Editorial. Environmental Geotechnics 7(3): 160-162, https://doi.org/10.1680/jenge.2020.7.3.160

Federico A, Vitone C, Murianni A and Internò G (2016) Plasticity of lime/ cement-stabilised dredged clayey sediments. Environmental Geotechnics 3(1): 17-27, https://doi.org/10.1680/envgeo.13.00076.

Gallagher PM and Mitchell JK (2002) Influence of colloidal silica grout on liquefaction potential and cyclic undrained behavior of loose sand. Soil Dynamics and Earthquake Engineering 22(9-12): 1017-1026, https:// doi.org/10.1016/S0267-7261(02)00126-4.

Geyer R, Jambeck JR and Law KL (2017) Production, use, and fate of all plastics ever made. Science Advances 3(7), https://doi.org/10.1126/ sciadv. 1700782 .

Ghadr S, Samadzadeh A, Bahadori H, O'Kelly BC and Assadi-Langroudi A (2021) Liquefaction resistance of silty sand with ground rubber additive. International Journal of Geomechanics 21(6), https://doi.org/ 10.1061/(ASCE)GM.1943-5622.0002002.

Goli VSNS, Mohammad A and Singh DN (2020) pplication of municipal plastic waste as a manmade neoconstruction materials: issues \& wayforward. Resources, Conservation and Recycling 161: 105008, https://doi.org/10.1016/j.resconrec.2020.105008.

Goli VSNS and Singh DN (2021) Comments on "incorporation of Xuanpaper waste residue in red mud/waste polyethylene composites". Journal of Hazardous Materials 404(Part A): 2, https://doi.org/10. 1016/j.jhazmat.2020.124164.

Gongora IAG and Palmeira EM (2012) Influence of fill and geogrid characteristics on the performance of unpaved roads on weak subgrades. Geosynthetics International 19(2): 191-199, https://doi.org/ 10.1680/gein.2012.19.2.191.

Griffin H and O'Kelly BC (2014) Sustainability of combined vacuum and surcharge preloading. In Proceedings of GeoCongress on the GeoCharacterization and Modeling for Sustainability (Abu-Farsakh M, Yu $\mathrm{X}$ and Hoyos LR (eds)). Geo-Congress 2014, ASCE, Atlanta, GA, USA, vol. 234, pp. 3826-3835.

GSHPA (2018) Thermal Pile Design, Installation and Material Standards. Ground Source Heat Pump Association, National Energy Centre, London, UK.

IGS (International Geosynthetics Society) (2021) Did You Know? \#2: Geosynthetics can greatly reduce the dependency on aggregates in infrastructure construction. International Geosynthetics Society (IGS) Sustainability Committee, Austin, TX, USA. See https://www. geosyntheticssociety.org/sustainability/ (accessed 2021/05/12).

Iniguez ME, Conesa JA and Fullana A (2019) Hydrothermal carbonization (HTC) of marine debris. Fuel 257, https://doi.org/10.1016/j.fuel.2019. 116033.

ITRC (Interstate Technology Regulatory Council) (2011) Green and Sustainable Remediation: A Practical Framework (GSR-2). Interstate Technology \& Regulatory Council, Green and Sustainable Remediation Team, Washington, DC, USA.

Jalal M, Nassir N and Jalal H (2019) Waste tire rubber and pozzolans in concrete: a trade-off between cleaner production and mechanical properties in a greener concrete. Journal of Cleaner Production $\mathbf{2 3 8}$ https://doi.org/10.1016/j.jclepro.2019.117882.

Jones DRV (2015) Using geosynthetics for sustainable development. Proceedings 2nd International GSI-Asia Geosynthetics Conference (GSI-Asia 2015), Seoul, South Korea, p. 4.

Jones M, Ruck T, Langdon N and Slattery J (2017) Reuse of Foundations. The Opportunities for Development. Oral Presentation, CGL, Godalming, UK. See https://www.cgl-uk.com/wp-content/uploads/ 2017/12/Reuse-of-Foundations-Presentation.pdf (accessed 07/23/ 2020).

Kondo JR, Roodi GH and Zornberg JG (2016) Evaluation of the interaction between dredged materials and geosynthetic reinforcements. In Proceedings of the 3rd Pan-American Conference on Geosynthetics. Minerva - Technology, Resources, and Information, Jupiter, FL, USA, vol. 2, pp. 1187-1202.

Krook J, Svensson N and Eklund M (2012) Landfill mining: a critical review of two decades of research. Waste Management 32(3): 513-520, https://doi.org/10.1016/j.wasman.2011.10.015.

Laloui L and Rotta Loria AF (2019) Analysis and Design of Energy Geostructures - Theoretical Essentials and Practical Application. Academic Press, Cambridge, MA, USA.

LEED (Leadership in Energy and Environmental Design) (2021) LEED Rating System, US Green Building Council, Washington, DC, USA. See https://www.usgbc.org/leed (accessed 17/01/2021).

Levesque CL, Locat J and Leroueil S (2007) Characterisation of postglacial sediments of the Saguenay Fjord, Quebec, Canada. In Characterisation and Engineering Properties of Natural Soils (Tan TS, Phoon KK, Hight DW and Lerouiel S (eds)). Taylor and Francis Group, London, UK, pp. $2645-2677$ 
Lopez G, Artetxe M, Amutio M et al. (2018) Recent advances in the gasification of waste plastics. A critical overview. Renewable and Sustainable Energy Reviews 82(Part 1): 576-596, https://doi.org/10. 1016/j.rser.2017.09.032.

Ma J, Wang J, Tian X and Zhao H (2019) In-situ gasification chemicallooping combustion of plastic waste in a semi-continuously operated fluidized bed reactor. Proceedings of the Combustion Institute 37(4): 4389-4397, https://doi.org/10.1016/j.proci.2018.07.032.

Magnusson S, Lundberg K, Svedberg B and Knutsson S (2015) Sustainable management of excavated soil and rock in urban areas - a literature review. Journal of Cleaner Production 93: 18-25, https://doi.org/10. 1016/j.jclepro.2015.01.010.

Miandad R, Kumar R, Barakat Ma et al. (2018) Untapped conversion of plastic waste char into carbon-metal LDOs for the adsorption of Congo red. Journal of Colloid and Interface Science 511: 402-410, https://doi.org/10.1016/j.jcis.2017.10.029.

Mitaritonna G, Antonino D, Raccuia F, Raccuia F and Vitone C (2013) I sedimenti del porto di Taranto: Caratterizzazione geotecnica e stabilizzazione con leganti. In Incontro Annuale dei Ricercatori di Geotecnica. IARG, Perugia, Italy (in Italian).

Mohamed AMO and El Gamal MM (2017) Process for the Preparation of a Product Comprising Modified Sulfur. European Patent EP2268592 B1, Mar.

Mohamed AMO and Paleologos EK (2018) Fundamentals of Geoenvironmental Engineering: Understanding Soil, Water, and Pollutant Interaction and Transport, 1st edn. Elsevier ButterworthHeinemann, Oxford, UK

Mohamed AMO, Paleologos EK and Howari F (eds) (2020) Pollution Assessment for Sustainable Practices in Applied Sciences and Engineering. Elsevier Butterworth-Heinemann, Oxford, UK.

Moosberg-Bustnes H, Lagerblad B and Forssberg E (2004) The function of fillers in concrete. Materials and Structures 37(74), https://doi.org/10. 1007/BF02486602.

MTES (2017) Guide de valorisation hors site des terres excavées issues de sites et sols potentiellement pollués dans des projets d'aménagement. Ministère de la Transition Écologique et Solidaire (MTES), Paris, France (in French)

National Research Council (1999) Groundwater and Soil Cleanup: Improving Management of Persistent Contaminants. The National Academies Press, Washington, DC, USA.

Ngo PL, Pramanik BK, Shah K and Roychand R (2019) Pathway, classification and removal efficiency of microplastics in wastewater treatment plants. Environmental Pollution 255(2): article 113326, https://doi.org/10.1016/j.envpol.2019.113326.

Nguyen VT, Wu N, Gan Y, Pereira J-M and Tang AM (2020) Longterm thermo-mechanical behaviour of energy pile in clay. Environmental Geotechnics 7(4): 273-248, https://doi.org/10.1680/ jenge.17.00160.

Nuzaimah M, Sapuan SM, Nadlene R et al. (2020) Sodium hydroxide treatment of waste rubber crumb and its effects on properties of unsaturated polyester composites. Applied Sciences 10(11): 3913 https://doi.org/10.3390/app10113913.

O'Connor D, Pan S, Shen Z et al. (2019) Microplastics undergo accelerated vertical migration in sand soil due to small size and wet-dry cycles. Environmental Pollution 249: 527-534, https://doi.org/10.1016/j. envpol.2019.03.092.

OECD (Organisation for Economic Co-operation and Development) (2020) Stat: Municipal Waste. Generation and Treatment. OECD, Paris, France. See https://stats.oecd.org/Index.aspx?DataSetCode=MUNW (accessed 20/07/2020)

Paleologos EK (2008) The lost value of groundwater and its influence on environmental decision-making. Risk Analysis 28(4): 939-950, https:// doi.org/10.1111/j.1539-6924.2008.01073.x.

Paleologos EK and Lerche I (1999) Multiple decision-making criteria in the transport and burial of hazardous and radioactive wastes.
Stochastic Environmental Research \& Risk Assessment 13: 381-395, https://doi.org/10.1007/s004770050045.

Paleologos EK, Caratelli P and El Amrousi M (2016) Waste-to-energy: an opportunity for a new industrial typology for Abu Dhabi. Renewable \& Sustainable Energy Reviews 55: 1260-1266, https://doi.org/10. 1016/j.rser.2015.07.098.

Paleologos EK, Elhakeem M and El Amrousi M (2018) Bayesian analysis of air emission violations from waste incineration and co-incineration plants. Journal Risk Analysis 38(11): 2368-2378, https://doi.org/10. 1111/risa.13130.

Paleologos EK, O'Kelly BC, Tang C-S et al. (2020) Post COVID-19 water and wastewater management to protect public health and geoenvironment. Environmental Geotechnics 8(3): 193-207, https:// doi.org/10.1680/jenge.20.00067.

Panno SV, Kelly WR, Scott J et al. (2019) Microplastic contamination in karst groundwater systems. Groundwater 57(2): 189-196, https://doi. org/10.1111/gwat.12862.

Papadimitriou CA, Krey G, Stamatis N and Kallianiotis A (2017) The use of waste mussel shells for the adsorption of dyes and heavy metals. Journal of Chemical Technology \& Biotechnology 92(8): 1943-1947, https://doi.org/10.1002/jctb.5247.

Peddaiah S, Burman A and Sreedeep S (2018) Experimental study on effect of waste plastic bottle strips in soil improvement. Geotechnical and Geological Engineering 36: 2907-2920, https://doi.org/10.1007/ s10706-018-0512-0.

Petti R, Marchi M, Plötze M, Puzrin AM and Vitone C (2022) Additivi a basso impatto ambientale per la stabilizzazione di sedimenti di dragaggio: effetti geotecnici. In XXVII Convegno Nazionale di Geotecnica. Associazione Geotecnica Italiana, Roma (in Italian), p. 7.

Qureshi MS, Oasmaa A, Pihkola H et al. (2020) Pyrolysis of plastic waste: opportunities and challenges. Journal of Analytical and Applied Pyrolysis 152, https://doi.org/10.1016/j.jaap.2020.104804.

Ragusa A, Svelato A, Santacroce C, Catalano P and Notastefano V (2021) Plasticenta: first evidence of microplastics in human placenta. Environment International 146, https://doi.org/10.1016/j.envint.2020. 106274.

Rammal D, Mroueh H and Burlon S (2020) Thermal behaviour of geothermal diaphragm walls: evaluation of exchanged thermal power. Renewable Energy 147(2): 2643-2653, https://doi.org/10.1016/j. renene.2018.11.068.

Reddy KR, Sadasivam BY and Adams JA (2014) Social sustainability evaluation matrix (SSEM) to quantify social aspects of sustainable remediation. In Proceedings of International Conference on Sustainable Infrastructure (Crittenden J, Hendrickson C and Wallace B (eds)). ASCE, Reston, VA, USA, pp. 831-841.

Reddy KR, Kumar G and Chetri JK (2019) Green and sustainable site remediation: incorporating broader economic impacts. In Proceedings of 17th African Regional Conference on Soil Mechanics and Geotechnical Engineering (ARCSMGE). ISSMGE, London, UK, pp. 575-579.

Roque AJ, Rodrigues GM and da Silva PF (2020) Re-cycling of construction and demolition waste and steel slag: characterization of the durability. Journal of Material Cycles and Waste Management 22 1699-1711, https://doi.org/10.1007/s10163-020-01061-y.

Sai GVSN, Pundik RC, Rao P and Kale GR (2018) Chemical looping combustion of biomass for renewable \& non-CO2 emissions energy status and review. International Journal of Engineering and Technology 7(2): 6-10, http://doi.org/10.14419/ijet.v7i2.1.9872.

Salimi K and Ghazavi M (2019) Soil reinforcement and slope stabilisation using recycled waste plastic sheets. Geomechanics and Geoengineering, https://doi.org/10.1080/17486025.2019.1683620.

Sani AK, Singh RM, Amis T and Cavarretta I (2019) A review on the performance of geothermal energy pile foundation, its design process and applications. Renewable and Sustainable Energy Reviews 106: 54-78, https://doi.org/10.1016/j.rser.2019.02.008. 
SedNet (2011) Dredging and sediment management European Sea Port. In Proceedings of the 7th International SedNet Conference. Deltares, Utrecht, the Netherlands. See https://sednet.org/events/sednet-conference-2011/ special-sessions/ (accessed 10/02/2021).

Shah N, Mavani V, Kumar V, Mungule M and lyer KKR (2019) Impact assessment of plastic strips on compressive strength of concrete. Journal of Materials in Civil Engineering 31(8), https://doi.org/10. 1061/(ASCE)MT.1943-5533.0002784

Shahrokhi-Shahraki R, Kwon PS, Park J, Park J and O'Kelly BC (2020) BTEX and heavy metals removal using pulverized waste tires in engineered fill materials. Chemosphere 242, https://doi.org/10.1016/j. chemosphere.2019.125281.

Shen $Y$ (2020) A review on hydrothermal carbonization of biomass and plastic waste to energy products. Biomass and Bioenergy 134, https:// doi.org/10.1016/j.biombioe.2020.105479.

Singh E, Kumar A, Khapre A et al. (2020) Efficient removal of arsenic using plastic waste char: Prevailing mechanism and sorption performance. Journal of Water Process Engineering 33, https://doi. org/10.1016/j.jwpe.2019.101095.

Singh E, Kumar A, Mishra R et al. (2021) Pyrolysis of waste biomass and plastics for production of biochar and its use for removal of heavy metals from aqueous solution. Bioresource Technology 320(Part A), https://doi.org/10.1016/j.biortech.2020.124278.

Sollecito F, Vitone C, Miccoli D et al. (2019) Marine sediments from a contaminated site: Geotechnical properties and chemo-mechanical coupling processes. Geosciences $\mathbf{9 ( 8 )}$, https://doi.org/10.3390/ geosciences 9080333 .

Soltani A, Deng A, Taheri A and O'Kelly BC (2019) Engineering reactive clay systems by ground rubber replacement and polyacrylamide treatment. Polymers 11(10): 1675, https://doi.org/10.3390/ polym 11101675 .

Soltani A, Taheri A, Deng A and O'Kelly BC (2020) Improved geotechnical behavior of an expansive soil amended with tire-derived aggregates having different gradations. Minerals 10(10): 923, https://doi.org/10. 3390/min10100923.

Soltani A, Raeesi R and O'Kelly BC (2021) Cyclic swell-shrink behaviour of an expansive soil treated with a sulfonated oil. In Proceedings of the Institution of Civil Engineers - Ground Improvement 1-14, https:// doi.org/10.1680/jgrim.19.00084

Sterpi D, Tomaselli G and Angelotti A (2020) Energy performance of ground heat exchangers embedded in diaphragm walls: field observations and optimization by numerical modelling. Renewable Energy 147(2): 2748-2760, https://doi.org/10.1016/j.renene.2018.11. 102.

SURF (Sustainable Remediation Forum) (2009) Integrating sustainable principles, practices, and metrics into remediation projects. Remediation 19(3): 5-114, https://doi.org/10.1002/rem.20210.

Tang AM, Hughes PN, Dijkstra TA et al. (2018) Atmosphere-vegetation-soil interactions in a climate change context; impact of changing conditions on engineered transport infrastructure slopes in Europe. Quarterly Journal of Engineering Geology and Hydrogeology 51(2): 156-168, http://doi.org/10.1144/qjegh2017-103.

Tang C-S, Paleologos EK, Vitone C et al. (2020) Environmental geotechnics: challenges and opportunities in the post COVID-19 world. Environmental Geotechnics 8(3): 172-192, https://doi.org/10. 1680/jenge.20.00054

Thai QB, Chong RO, Nguyen PTT et al. (2020) Recycling of waste tire fibers into advanced aerogels for thermal insulation and sound absorption applications. Journal of Environmental Chemical Engineering 8(5), https://doi.org/10.1016/j.jece.2020.104279.

Thomas BS and Gupta RC (2016) A comprehensive review on the applications of waste tire rubber in cement concrete. Renewable and Sustainable Energy Reviews 54: 1323-1333, https://doi.org/10.1016/j. rser.2015.10.092.
Tsagarakis KP (2020) Shallow geothermal energy under microscope: social, economic, and institutional aspects. Renewable Energy 147(2): 2801-2808, https://doi.org/10.1016/j.renene.2019.01.004.

Tsagarakis KP, Efthymiou L, Michopoulos A et al. (2020) A review of the legal framework in shallow geothermal energy in selected European countries: need for guidelines. Renewable Energy 147(2): 2556-2571, https://doi.org/10.1016/j.renene.2018.10.007.

Tsubakihara Y and Yamashita K (2005) Reuse of existing piles in building reconstruction and its environmental effects. In Proceedings of the World Sustainable Building Conference. ICONDA ${ }^{\circledR C I B l i b r a r y}$, Rotterdam, the Netherlands, pp. 2675-2682.

USEPA (U.S. Environmental Protection Agency) (2008) Green Remediation: Incorporating Sustainable Environmental Practices into Remediation of Contaminated Sites. USEPA, Washington, DC, USA, EPA-542-R-08-002.

USEPA (2014) Municipal Solid Waste Generation, Recycling and Disposal in the United States: Facts and Figures for 2012. USEPA, Washington, DC, USA. See https://archive.epa.gov/epawaste/nonhaz/ municipal/web/pdf/2012_msw_fs.pdf (accessed 23/06/2020).

USEPA (2015) Effluent Limitations Guidelines and Standards for the Steam Electric Power Generating Point Source Category; Final Rule; 40 CFR Part 423. USEPA, Washington, DC, USA. See https://www. ecfr.gov/cgi-bin/text-idx?SID=6b51273d47e8dc451e0aac10 f60 cdfee $\& m c=$ true $\&$ node $=$ pt40.31.423\&rgn= div5 $($ accessed 03/07/ 2020).

USEPA (2020a) Overview of EPA's Brownfields Program: EPA's Brownfields \& Land Revitalization Program Overview. USEPA, Washington, DC, USA. See https:/www.epa.gov/brownfields/ overview-epas-brownfields-program (accessed 08/01/2021).

USEPA (2020b) Facts and Figures about Materials, Waste and Recycling: National Overview: Facts and Figures on Materials, Wastes and Recycling. USEPA, Washington, DC, USA. See https://www.epa.gov/ facts-and-figures-about-materials-waste-and-recycling/nationaloverview-facts-and-figures-materials\#: :text=These $\% 20 \mathrm{Facts} \% 20$ and $\%$ 20Figures $\% 20$ are, $27 \% 20$ million $\% 20$ tons $\% 20$ were $\% 20$ composted (accessed 18/07/2020).

Vargas C and Hanandeh AE (2021) Systematic literature review, metaanalysis and artificial neural network modelling of plastic waste addition to bitumen. Journal of Cleaner Production 280(Part 1), https://doi.org/10.1016/j.jclepro.2020.124369.

Vaverková MD, Paleologos EK, Dominijanni A et al. (2020) Municipal solid waste management under COVID-19: challenges and recommendations. Environmental Geotechnics 8(3): 217-232, https:// doi.org/10.1680/jenge.20.00082.

Vitone C, Federico A, Puzrin A et al. (2016) On the geotechnical characterization of the polluted submarine sediments from Taranto. Environmental Science and Pollution Research 23: 12535-12553, https://doi.org/10.1007/s11356-016-6317-x.

Vitone C, Sollecito F, Todaro F and Vera C (2020) Contaminated marine sites: geotechnical issues bridging the gap between characterization and remedial strategies. Rivista Italiana di Geotecnica 4: 41-62, https://doi.org/10.19199/2020.4.0557-1405.041.

Wang D, Abriak N, Zentar R and Xu W (2012) Solidification/stabilization of dredged marine sediments for road construction. Environmental Technology 33: 95-101, https://doi.org/10.1080/09593330.2011. 551840.

Wang L, Kwok J, Tsang D and Poon C-S (2015) Mixture design and treatment methods for recycling contaminated sediment. Journal of Hazardous Materials 283: 623-632, https://doi.org/10.1016/j.jhazmat. 2014.09.056.

Wang Y, Wang HS, Tang CS, Gu K and Shi B (2018) Remediation of heavy-metal-contaminated soils by biochar: a review. Environmental Geotechnics 1-14, https://doi.org/10.1680/jenge.18. 00091. 
Wood DW (2013) Briefing: Biological routes to improvement of geomaterials. Proceedings of the Institution of Civil Engineers Construction Materials 166(4): 190-194, http://doi.org/10.1680/coma. 12.00039 .

Yaqub M and Lee W (2019) Zero-liquid discharge (ZLD) technology for resource recovery from wastewater: a review. Science of the Total Environment 681(1): 551-563, https://doi.org/10.1016/j.scitotenv.2019. 05.062 .

Yonkos LT, Friedel EA, Perez-Reyes AC, Ghosal S and Arthur CD (2014) Microplastics in four estuarine rivers in the Chesapeake Bay, USA.
Environmental Science and Technology 48: 14195-14202, https://doi. org/10.1021/es5036317.

Yung WH, Yung LC and Hua LH (2013) A study of the durability properties of waste tire rubber applied to self-compacting concrete. Construction and Building Materials 41: 665-672, https://doi.org/10. 1016/j.conbuildmat.2012.11.019.

Zhao P, Huang N, Li J and Cui X (2020) Fate of sodium and chlorine during the co-hydrothermal carbonization of high-alkali coal and polyvinyl chloride. Fuel Processing and Technology 199, https://doi. org/10.1016/j.fuproc.2019.106277.

\section{How can you contribute?}

To discuss this paper, please submit up to 500 words to the editor at journals@ice.org.uk. Your contribution will be forwarded to the author(s) for a reply and, if considered appropriate by the editorial board, it will be published as a discussion in a future issue of the journal. 